\title{
Teletandem language learning in a technological context of education: interactions between Brazilian and German students
}

\author{
Aprendizagem de línguas em regime de teletandem em um \\ contexto tecnológico de educação: interações \\ entre alunos brasileiros $e$ alemães
}

\author{
Suelene Vaz da SILVA \\ (Instituto Federal de Educação, Ciência e Tecnologia de Goiás, Brazil) \\ Francisco José Quaresma de FigueIREDO \\ (Universidade Federal de Goiás, Brazil)
}

\section{ABSTRACT}

This paper presents data from a computer-mediated communication study conducted between a group of Brazilian university students - from Instituto Federal de Educação, Ciência e Tecnologia do Estado de Goiás, Campus Goiânia, Goiás, Brazil - who wanted to learn English, and a group of German university students - from the University of Worms, in Germany - who wanted to learn Portuguese. The cross-cultural bilingual communication was conducted in the second semester of 2010 and involved discussions on environmental issues. Adopting a qualitative perspective in the analysis, the data were derived from conversation sessions through a webconferencing software known as Openmeetings and through e-mails and some written activities developed by the students. All these were analyzed by means of sociocultural theory. Among the conclusions we reached, we observed that the participants used the software features to help them in their language learning process, discussed issues related to environmental science, as well as topics related to their personal and academic life. Regarding the languages used, the participants used English 
during the teletandem sessions as an anchoring language to assist their partners in learning English itself and Portuguese, as well as introduced the German language in the interaction sessions.

Key-words: Language learning; Teletandem; Environmental issues; Collaborative learning.

\section{RESUMO}

Este trabalho apresenta dados de um estudo realizado com estudantes universitários brasileiros - do Instituto Federal de Educação, Ciência e Tecnologia do Estado de Goiás, Campus Goiânia, Goiás, que queriam aprender Inglês e estudantes universitários alemães - da Universidade de Worms, na Alemanha - que desejavam aprender Português. A comunicação bilíngue intercultural foi realizada no segundo semestre de 2010 e envolveu discussões sobre questões ambientais. A adoção de uma perspectiva qualitativa na análise dos dados foi obtida a partir de sessões de conversação através de um software de webconferência conhecido como Openmeetings, de e-mails e de atividades escritas desenvolvidas pelos alunos. Os dados foram analisados com base na teoria sociocultural. Entre as conclusões a que chegamos, observamos que os participantes utilizaram recursos do software para lhes auxiliar no processo de aprendizagem das línguas, discutiram temas relativos à ciência ambiental, bem como a assuntos relacionados à sua vida pessoal e acadêmica. Quanto às línguas utilizadas, os participantes usaram inglês durante as sessões de teletandem como língua de ancoragem para auxiliar seus parceiros na aprendizagem do próprio inglês e do português, bem como introduziram a língua alemã nas sessões de interação.

Palavras-chave: Aprendizagem de linguas; Teletandem; Temas sobre o meio ambiente; Aprendizagem colaborativa.

\section{Introduction}

The insertion of Information and Communications Technology (ICT) in the language learning education context sparked new perspectives to the teaching of foreign languages (Araújo \& Araújo 2013, Chinnery 2014, Paiva 2001, Silva 2012, Telles 2009a, 2009b, Vassallo \& Telles 2006, 2009, Warschauer 1996) because technology 
provided learners with some resources which allowed them to significantly interact with other people and thus to have the chance to learn collaboratively with a peer (Figueiredo 2006, Forman \& Cazden 1985).

One of the great benefits observed when learners work in pairs or in groups is the fact that interaction maximizes the social dimension of the learning process. It also maximizes the acquisition of new languages by providing learners not only with opportunities for both input and output, but also with opportunities for negotiation and sharing and coconstruction of knowledge (Figueiredo 2006, Foster 1998, Gass 1997, Long \& Porter 1985, Mackey 1999, Oxford 1997, Pica 1991, 1994, Swain, Brooks \& Tocalli-Beller 2002, Swain \& Lapkin 1998, Vygotsky 1978, Warschauer 1997). Interaction is necessary for language learning to occur because, by modifying the input and turning it into output, learners also expand opportunities to understand and to internalize, beyond the meaning of the message, the linguistic structure of the language (Swain 1995, 2000).

In the virtual world, collaborative learning is also known as telecollaboration and it is defined as "the application of the global communication network in the teaching and learning processes" (Belz 2002: 61) and it involves computer-mediated interactions between speakers of different languages. By interacting with people from different countries, learners also have the chance to talk about cultural aspects related to their country or place where they live in (see Leone 2014; also see Carvalho, Messias \& Diaz; Santos; and Telles in this issue).

Among the many virtual tools that can be used as a language learning context, teletandem has proved to be an innovative, and successful context to provide students with opportunities to communicate with people from different regions of the world and, for instance, to learn foreign languages (Benedetti, Consolo \& VieiraAbrahão 2010, Hasnawi 2013, Telles 2009a).

In this paper, we are going to present data that show that teletandem can be used in technological contexts, not only as a tool to aid the learning of languages, but also to enhance the learning and sharing of knowledge related to the area in which the interlocutors are specializing. 


\section{The principles of tandem and teletandem language learning}

The basic principles guiding tandem and teletandem learning are separation of languages, reciprocity, and autonomy. The observance of all these three principles makes it possible for the interactants to succeed in the learning of foreign languages. However, this success is also related to other peculiarities, such as learners' individual characteristics, positive attitudes and enthusiasm to build an intercultural interaction and more symmetrical relationships between the members of the pair, which may provide a reduction of the affective filter (Brocco 2010, Cavalari 2009, 2010, Souza 2003, Vassallo \& Telles 2009).

The basic guiding principles of tandem learning, established by the International Tandem Network, were named somewhat differently during the spread of this mode of learning. However, despite the deletion or addition of any of the principles, the main ideas behind tandem learning remain unchanged. O'Dowd (2011), for example, considers as tandem guiding principles only learner autonomy and reciprocity, although the author emphasizes the importance of balance in time devoted to each language use (separation of languages: languages must not be mixed during the tandem sessions). For the author, it is important that each member of the pair of learners has the same amount of time to learn the other's language, teach their partner the language of their competence through authentic input, as well as to receive and provide corrective feedback.

It is relevant that the interactants contemplate using one language at a time during the interactions, ensuring thus the balance in time devoted to each language use. Moreover, the use of separate languages challenges and motivates the learners to use the target language instead of using their own mother tongue, which would be much easier for them (Vassallo \& Telles 2009).

The use of one language at a time is important to ensure that each learner will have similar opportunities to practice the target language in authentic communication (Brocco 2010, Vassallo \& Telles 2006). A session of tandem learning is composed of two parts, which can be performed on the same day or on different days. Therefore, each part 
must include the use of only one of the target languages, which will be alternated in the second part of the session (Vassallo \& Telles 2009). This principle refers to the balance of the amount of time to be devoted to each language in each session and it "assures that both partners will also have their respective chances to communicate in the language in which they are proficient" (Vassallo \& Telles 2006: 87). Separation of languages also includes the idea of reversing roles between the pair of learners, who are, in the first part of the session, the ones who learn the other's language, and, in the second part, they act as someone who assists their partner in the learning of the target language (Benedetti 2010). This reversal of roles is an attribute of the second principle of tandem learning: reciprocity.

Reciprocity is also intended to ensure the balance of the amount of time to be devoted to each language, and especially the role played by the members of the pair: one who learns the other's language, and one who helps the partner in the learning of their own language (Brammerts 2002, Telles \& Vassallo 2009, Vassallo \& Telles 2006). This alternation of roles - learner/tutor - not only motivates learners, but also promotes free and mutual exchange of knowledge regarding language and culture (Luz 2010, Vassallo \& Telles 2009).

Concerning the hierarchical position that the pair of students have in the tandem teaching-learning process, despite the switching of roles, they are learners, and not teachers, and, as such, they feel more comfortable taking risks in learning each other's language than they would feel in the presence of a teacher in a classroom (Brocco 2010, Cavalari 2009, 2010, Vassallo \& Telles 2009). In tandem learning, "it is not the role of the learners to teach each other their native language, for tandem learners never teach, but help the partner learn" (Brammerts 2002: 21). However, in teletandem learning context, the roles - teacher/learner - carried out by the teletandem partners mingle. The participants end up influencing or even intervening in the learning process of the tandem partner, which can be considered as teaching (Vassallo \& Telles 2006).

The principle of autonomy comprises a commitment between the teletandem partners who plan the interaction sessions according to their needs, schedule the date and time of the sessions, determine 
which language is going to be used in each session, and make decisions about the topics of the interaction (Cavalari 2010, Leone 2014, Telles 2009, Vassallo \& Telles 2006).

It is important to pinpoint that the three principles of tandem/ teletandem learning - separation of languages, reciprocity and autonomy - are interdependent, since they work together in the composition of the tandem/teletandem learning context (Brammerts 1996, Cavalari 2009, Leone 2014, Souza 2003, Vassallo \& Telles 2006).

Vassallo and Telles (2006: 193, emphasis in the original) articulate the six principles that characterize teletandem:

1. Teletandem is a new distance and computer assisted mode of learning foreign languages in-tandem that makes extemporaneous use of oral and written production, reading and listening comprehension and webcam images of the participants.

2. Teletandem procedures are carried out on bases of commonly agreed and shared principles of reciprocity and autonomy between two participants.

3. Teletandem participants are two people interested in studying each other's language at a distance in a relatively autonomous way. We say "relatively autonomous" because they can resort to a teacher's professional mediation, if they wish or if they need so.

4. Teletandem participants are (reasonably) competent speakers of the respective languages. They may or may not be native speakers of the target languages. They are not professional teachers.

5. Teletandem teaching/learning processes are accomplished through the development of regular and didactically aimed sessions of free audio/video distant conversations.

6. These free conversations are followed by shared reflection during which reading and writing abilities are practiced. These reflections may focus on content, culture, form, lexicon and the process of Teletandem interaction itself. The reading and writing practices can also take the form of regular $e$-tandem practices, such as exchange of written homework assignments by e-mail, when language feedback and meaningful vocabulary and grammar inputs are given by the Teletandem partner.

Thus, the learning context in teletandem differs from previous tandem learning contexts in that a member of a teletandem partnership does not necessarily have to be a native speaker of the language he/she is 
going to assist the partner with, but someone who is a competent speaker of that language (Telles 2009b, Vassallo \& Telles 2006, 2009).

\section{Methodology}

The Instituto Federal de Educação, Ciência e Tecnologia do Estado de Goiás (IFG), in Brazil, the University of Trier, and the University of Worms, in Germany, were the participant institutions in this telecollaborative language learning project. The IFG is an institution that works primarily with technical (high school) and technological (higher education) courses. The technological courses have an average duration of three years. They have a specific academic focus and aim to train professionals to meet specific labor-market fields. On the other hand, the German institutions work with higher education and graduate programs.

Openmeetings was the communication software used for the teletandem sessions. It is a free software which allows for teleconference with the following components and functions: microphone and webcam, chat, whiteboard, screen sharing, file download and audio and video recording. Figure 1 illustrates Openmeetings conference room.

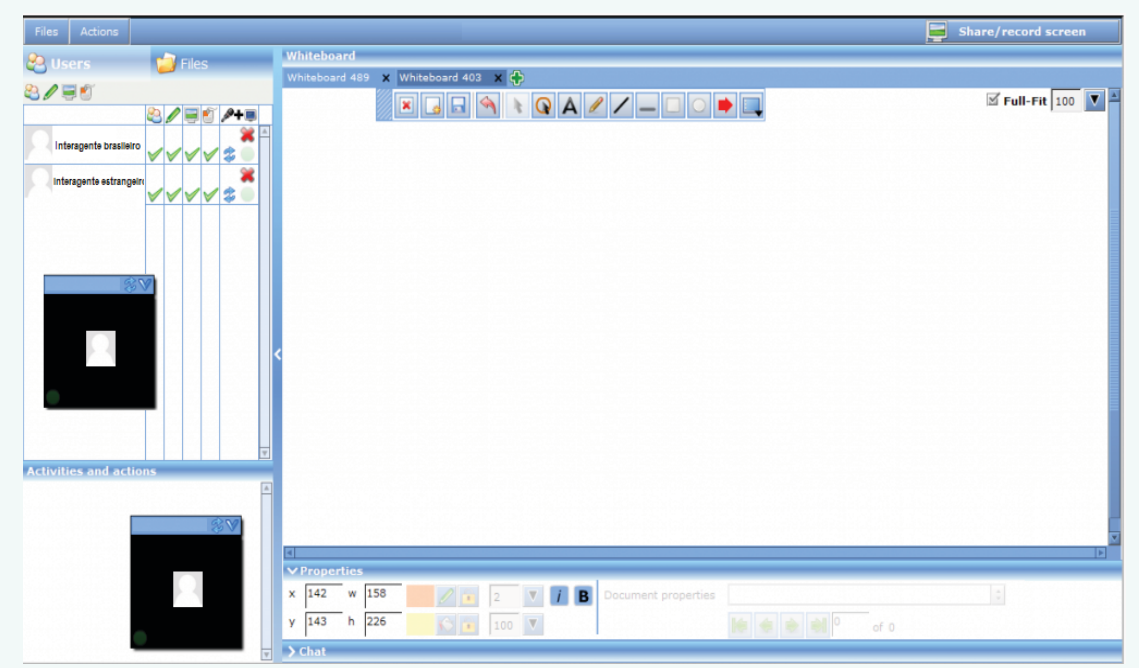

Figure 1 - Openmeetings conference room. 
A series of steps were taken before initiating the teletandem sessions. First of all, a list with the names of 11 students from the University of Worms and one student from the University of Trier was sent to IFG. Then, IFG produced a list of Brazilian learners with 23 volunteers. From that list, the first 12 students who signed up were selected to form partnerships with the foreign learners. After that, Brazilians and the foreign students made a first contact by email, to establish the partnerships and to allow the pairs of students to suggest days and times for their first interaction. Finally, the pairs scheduled the teletandem sessions according to their own availability.

This paper is illustrated with data from three IFG Brazilian students and three German students, two from the University of Worms and one from the University of Trier.

The data examined in this study attempted to answer three research questions:

a) How were the videoconference tools of Openmeetings used by the participants during teletandem sessions?

b) How have the participants engaged in the language learning process?

c) What tasks have they developed considering issues related to sustainable tourism?

As for the language pair involved in this study, it is important to mention that in IFG undergraduate courses the foreign languages taught are English, Spanish, and French. As the Brazilian learners wished to enhance their knowledge of English, this was the language chosen by them to be crafted with Portuguese in the teletandem sessions. Since the German students were proficient in English, they assisted their Brazilian partners in the learning of this language and were assisted by them in the learning of Portuguese.

We must emphasize that the teletandem sessions via Openmeetings were not aimed only at providing the students with opportunities to learn a target language, but also at giving them the chance to talk about issues related to environmental science, which is an area of interest of both German and Brazilian participants. So they should 
discuss, during interactions in teletandem, issues related to sustainable tourism, as it was planned that the German students would travel to Brazil, particularly to the State of Goiás, to visit some tourist areas and develop, with their Brazilian counterparts, a study on 'sustainability and tourism'.

Thus, the participants had to select from the theme 'sustainability and tourism' a subtheme they would like to investigate during the stay of the German students in the state of Goiás, which would be the main topic for their interactions. After the visits, the students had to do some tasks: they had to make a poster and to write a paper on the subthemes they had chosen. Table 1 shows the participants, identified by their pseudonyms, their educational level, as well as the subthemes discussed by them during the teletandem sessions.

Table 1 - Participants identified by their pseudonyms and the subthemes discussed by them during the teletandem sessions

\begin{tabular}{|c|c|c|}
\hline \multicolumn{2}{|l|}{ Participants } & \multirow{2}{*}{ Subthemes discussed } \\
\hline Brazilian & German & \\
\hline $\begin{array}{l}\text { Natalie } \\
\text { (Undergraduate in } \\
\text { Tourism) }\end{array}$ & $\begin{array}{l}\text { Teego } \\
\text { (M.A. in Tourism) }\end{array}$ & $\begin{array}{l}\text { Management concepts for } \\
\text { sustainable destination }\end{array}$ \\
\hline $\begin{array}{l}\text { Gustavo } \\
\text { (Undergraduate in } \\
\text { Hospitality) }\end{array}$ & $\begin{array}{l}\text { Lini } \\
\text { (B.A. in Tourism and Travel } \\
\text { Management) }\end{array}$ & Sustainable tourism \\
\hline $\begin{array}{l}\text { Jujuba } \\
\text { (Undergraduate in } \\
\text { Tourism) }\end{array}$ & $\begin{array}{l}\text { Peregrino } \\
\text { (M.A. in Environmental } \\
\text { Planning) }\end{array}$ & $\begin{array}{l}\text { Performance measurement } \\
\text { systems in sustainable tourism }\end{array}$ \\
\hline
\end{tabular}

The tourist sites visited in the State of Goiás were: (1) Brasília, the national capital of Brazil; (2) Chapada dos Veadeiros National Park, a nature reserve; (3) Santa Branca Ecological Farm, which has a sustainable leisure and residential area, located in the city of Teresópolis; (4) Rio Quente Resorts, famous for its hot water springs; and (5) the historic city of Pirenópolis. Table 2 shows these destinations and the purpose of the visit to each of them. 
Table 2 - Places visited in Goiás and the activities developed in each of them

\begin{tabular}{|l|l|}
\hline Place visited & Purpose of the visit \\
\hline $\begin{array}{l}\text { Brasília (Capital of } \\
\text { Brazil) }\end{array}$ & $\begin{array}{l}\text { The students visited the main monuments in the city, as } \\
\text { well as an ecological restaurant and a hotel. }\end{array}$ \\
\hline $\begin{array}{l}\text { Chapada dos } \\
\text { Veadeiros National } \\
\text { Park }\end{array}$ & $\begin{array}{l}\text { The students went to Chapada dos Veadeiros National Park } \\
\text { to visit the Federal Protection Unit to verify actions taken } \\
\text { to preserve the place. }\end{array}$ \\
\hline $\begin{array}{l}\text { Santa Branca } \\
\text { Ecological Farm }\end{array}$ & $\begin{array}{l}\text { The students visited Santa Branca Ecological Farm to } \\
\text { understand the sustainable development projects for the } \\
\text { farm, which include leisure, housing and environmental } \\
\text { education. }\end{array}$ \\
\hline Rio Quente Resort & $\begin{array}{l}\text { The students visited Rio Quente Resort to verify the degree } \\
\text { of sustainability of the resort and the legal use of natural } \\
\text { resources. }\end{array}$ \\
\hline Pirenópolis & $\begin{array}{l}\text { The students went to Pirenópolis to visit the historical } \\
\text { part of the city and check if there are policies related to } \\
\text { sustainable tourism. }\end{array}$ \\
\hline
\end{tabular}

The teletandem interactions occurred from August $28^{\text {th }}$ to September $4^{\text {th }}, 2010$, and were audio- and video-recorded by means of the communication software itself. The data analysed in this paper comprise eight teletandem sessions which were transcribed verbatim as well as some excerpts from the students' written tasks (poster and paper). Data derived from the interactions between Natalie and Teego constitute the main source of data for our analysis. The languages used in the interactions were mostly English and Portuguese, as previously defined, but we could see that some words in German were also included in the interactions.

\section{Results and Discussion}

Data analysis will be done in three parts. At first, we present how the participants used the videoconference tools of Openmeetings. In the second part, we analyze the process of language learning in which the participants engaged. In the last part, we present some of the interactions in which the participants discussed 'sustainability' and 'tourism' and the results of these interactions. Data were accurately kept in the language used by the participants. 


\subsection{The participants use of Openmeetings resources}

This initial example refers to an interaction held by Natalie and Teego. We can see in this example and in the others that follow, that the languages the students are learning or improving are mingled in the interaction. In fact, this is very commom in interactions where the interlocutors speak different languages and, in some cases, they even make use of other foreign languages in which they are proficient to make themselves understood (cf. Luvizari-Murad 2011).

In example [1], we observe the use of audio and chat as auxiliary resources used by the participants to make their message understood. Teego asks Natalie how to say 'is' in Portuguese for him to build the sentence 'Where's the chocolate?'(Onde está o chocolate?). However, as the verb 'be' corresponds to two verbs in Portuguese: 'ser' and 'estar', Nalalie thinks that Teego wanted to learn the verb 'ser' to ask "What is chocolate?" (O que é chocolate?), and teaches him to say 'é'. Then she realizes that, in fact, he wanted to know where her chocolate bar was, and she teaches him how to say 'está'. This miscommunication is cleared up by the oral negotiation the partners engage in and by the aid of writing resources, through the use of chat, as shown in the following example.

[1] - Interaction via Openmeetings

Teego: What is the word 'is' in Portuguese?

Natalie: Ah, 'is', 'é'.

Natalie: [Chat] é

Teego: Ah, onde é chocolate?

Natalie: I don't understand the question.

Teego: No? (He looks surprised)

Natalie: No.

Teego: Onde é chocolate?

Natalie: No, but... for us chocolate is only a name, a substantive.

Teego: [Chat] onde é Chocolate?

Natalie: Onde? Onde...

Teego: Um, like 'where is the chocolate'?

Natalie: No, because chocolate for us is not a... is not a word that you use capital letter, is only a substantive.

Teego: Ok.

Natalie: 'Onde' is for, for places.

Teego: Ah! Which would be for 'the chocolate', when I search for chocolate...

Natalie: What? 
Teego: ...but I don't know where the chocolate is, but you know. I wanna know where it is, what do I ask?

Natalie: Yes, it is because onde is ...

Natalie: [Chat] onde $=$ where

Natalie: 'where' is for places. But if you want to know, what is chocolate, you have to ask.

Teego: Where is the chocolate, if I don't know where it is.

Natalie: No... I don't understand, if you want to know what is chocolate, you have to ask 'O que é chocolate?'

Teego: [Chat] where is the chocolate? I can't find it.

Natalie: Ah yes! I understand now, yes, yes, it is here next to me, my chocolate that you ask, yes.

Teego: So I have to ask, hum, 'o que é chocolate?' In the closet?

Natalie: No, no. 'O que é chocolate', no, but you want to know where is my chocolate, is this that you want to know?

Teego: Yes.

Natalie: Ah, ok, no, so, is this the question, is this 'Onde está o chocolate?'

Natalie: [Chat] onde está o chocolate?

Teego: Ah, 'está'?

Natalie: Yes, is this the word I don't understand.

Teego: Only one word wrong, come on!

Natalie: Yes. This 'Onde está o chocolate?'

Teego: Ok.

The participants also used the chat tool when the audio equipment was not working properly, either because of equipment problems or because they could not fine-tune the audio equipment. The following example illustrates a fragment of a conversation held by Natalie and Teego, through chat, because the microphone used by Natalie starts having some problems. Then Teego uses audio and chat to assist his partner in solving the problem.

[2] - Interaction via Openmeetings

Natalie: [Chat] My microphone is not good today.

Teego: [Chat] No problem ... take your time

Natalie: [Chat] can you listen me?

Teego: No. Can you hear me?

Natalie: [Chat] no, I can't hear to you

Teego: But can you listen to me or can you hear me? Perhaps now. I can't see you either, so your webcam is off as well.

Natalie: [Chat] I am listening you very bad, but the problem is here. 
Today I am in another place and here is terrible... I'm sorry ...

Teego: [Chat] ok, so what shall we do? Start perhaps over again ... just leave the room and enter again, or what do you think?

Natalie: [Chat] yes, I will try. Thank you.

The webcam, in addition to enabling the interactants to see each other, allowed them to show their partner things they considered to be important for them. In example [3], Natalie makes use of the webcam to show Teego her pet dog. This familiarity with the context of the partner contributes to create ties of affection between learners, even being geographically distant from each other (cf. Salomão in this issue). Natalie becomes closer to Teego when she virtually allows him to enter her home and see her pet. It is also this fact that leads Natalie to practice English because she engages into a conversation about pets with Teego and they talk about the fact that there are similarities in the way people give names to pets in Brazil and in Germany.

[3] - Interaction via Openmeetings

Natalie: My sister was talking to me to show my dog for you, but I don't know where is her, my sister will pick up her.

Teego: What's her name again?

Natalie: What? The name?

Teego: Yeah, what's her name again?

Natalie: Of my dog? Bebel. (She shows Teego her dog through the webcam)

Teego: Yeah, ok. Yeah, very cute.

Natalie: Yes, very cute... very fat too. But everybody here love her so much, our baby.

Teego: So you feed her a lot.

Teego: The name of the $\operatorname{dog} \ldots$

Natalie: Ah, ok, is ...

Natalie: [Chat] Bebel

Natalie: Bebel.

Teego: Bebel, doesn't it mean anything?

Natalie: No, it doesn't mean.

Teego: Ok.

Natalie: Nothing specifically, but here is the name of...

Teego: Is it typical for dogs to have names like that?

Natalie: Yes, yes, is this that I would say, yes, is typical for dogs, but here in Brazil has a lot of dogs and cats and another kinds of animals that has names from person, people. In Germany, this is common too? 
Teego: What do you wanna know?

Natalie: Another names for dogs? Yes, she...

Teego: No, what did you want to ask me in Germany?

Natalie: Ah, yes, if, if it is common there they put people's names in animals?

Teego: Yeah, quite common.

Natalie: Is common too?

Teego: Yes.

The whiteboard - another feature of Openmeetings - is also used by the participants as an auxiliary communication resource and, by extension, for language learning. In the following excerpt, Natalie uses the whiteboard to show Teego some pictures of the institution where she studies. As Natalie talks about the institution, the pictures illustrate the place and enable Teego to have an idea about the place that he would visit soon. The picture, in the following excerpt, depicts the courtyard of the IFG that is often used to host internal and external community events.

\section{[4] - Whiteboard-Openmeetings}

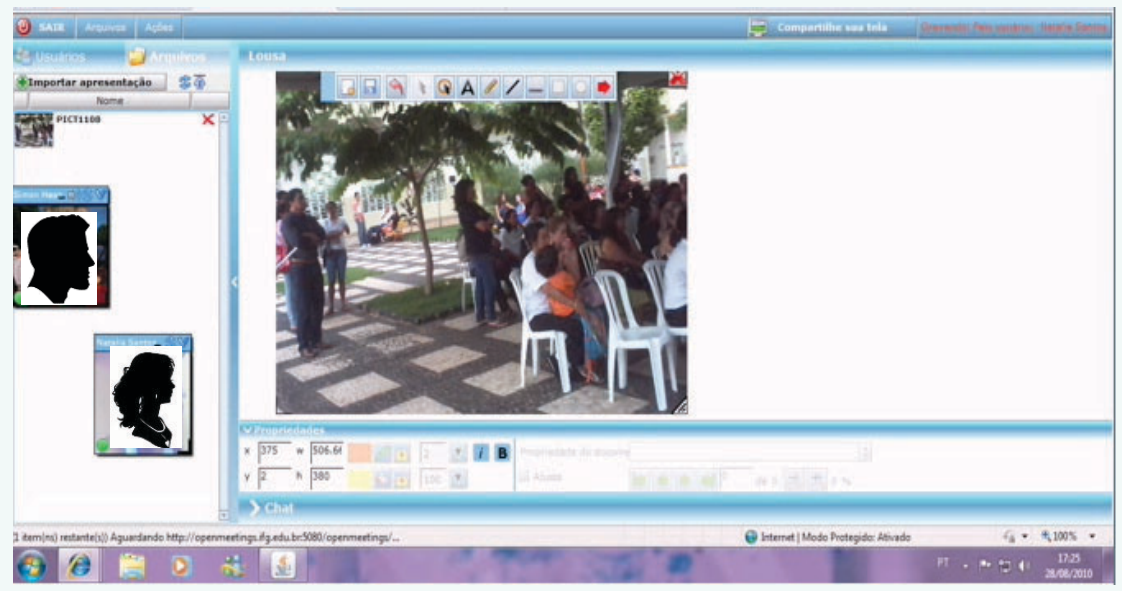


Natalie: Yes? (She posts a picture of the courtyard of IFG on the whiteboard)

Teego: Yep.

Natalie: And this one day that have some event there and has, have, had a lot of people, but is very, very big here. You will know.

Teego: Yeah. Only another two, three weeks, yeah.

Natalie: Yes. More or less three weeks. But I think we will...

Teego: I think that's gonna be fun.

Natalie: Yes, me too. We will go a side tour, a tour in IFG ... that is the name of my institution.

Teego: Ok. Mhm.

Natalie: Is very big there.

By sharing the picture with Teego, not only does Natalie anticipate his visit to the institution, but she also shares with him a very familiar space for her, which corroborates the statements of Brammerts (1996) and Vassallo and Telles (2009) that, in teletandem learning, the participants work together not only to learn languages, but also to learn more about the personality and culture of the partner.

Gustavo, in the following example, uses the whiteboard as a complementary resource to illustrate what he was explaining to his partner. Lini asks Gustavo how to say 'without' in Portuguese, as she is trying to build the sentence 'I am a student' in both affirmative and negative forms. Gustavo then helps her by means of both oral and written feedback. However, Lini, probably from the two forms of aid offered by Gustavo, realizes that the word she needs is not the word 'without' in Portuguese. She then builds the sentences 'I am a student' (sou estudante) and 'I'm not a student' (eu não sou uma estudante), which are confirmed by Gustavo to be correct. He then reinforces the sentences produced by Lini by writing the sentence 'eu sou estudante' on the whiteboard, as can be seen in the following example. 
[5] - Interaction via Openmeetings

Gustavo: Take a look at the whiteboard, please. Let me find something here. Just a second. Eu sou estudante, Lini.

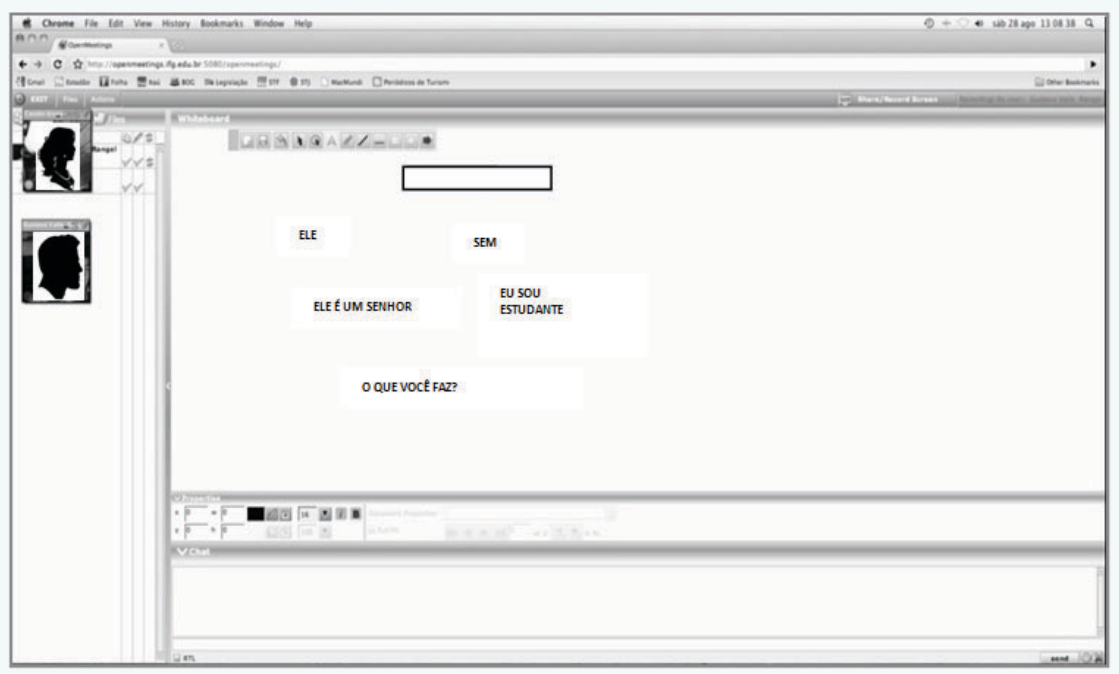

Lini: Estudante.

Gustavo: Exato. Estudante.

Lini: Eeh ...

Gustavo: Eu sou

Lini: Como é 'without'?

Gustavo: 'Sem'. 'Without' é 'sem'.

Lini: Ok. Sem uma?

Gustavo: Sem uma. I didn't catch you. What do you wanna say?

Lini: Não. El frase, no, o frase is 'sou estudante' e 'eu não sou uma estudante'.

Gustavo: Ah, yes. They are both correct. As duas estão certas. Eu sou uma estudante. As duas estão certas. Both are correct.

Lini: Ah, bom. Mhm.

Gustavo: Sometimes I think that you know Portuguese better than me [he laughs].

Teletandem language context promotes learners' creativity in the use of the variety of resourses offered by the software. Their skills to use microphone and webcam, whiteboard, electronic dictionaries associated with their personal background and level of autonomy 
avail not only their target language practice but also take into account the collaborative process of language learning. Similar results were also found by Consolo \& Furtoso (in this issue). The next section will provide some examples of language practice.

\subsection{The process of language learning the participants engaged in}

In example [6], while the participants were talking about tourist destinations in Goiás, Natalie has the idea to send Teego, via Openmeetings, some pictures of the places the Germans would visit in Goiás to collect data for the task they were developing on sustainability. She then realizes that she does not know how to say the Portuguese word 'verificar' in English. So she hypothesizes that 'verificate' is the appropriate word. To confirm her hypothesis, Natalie makes use of her mother tongue as scaffolding to check if her hypothesis is true. Teego then provides her with the correct word in English and Natalie uses the word 'verify' in her speech.

[6] - Interaction via Openmeetings

Natalie: No, ok, and then I have that I can to, to show for you the photos about our cities... in this program Openmeetings, I will, I will... pass, I will see 'verificate', 'verificate'? Exists this word? This word 'verificar'?

Teego: 'Verify'.

Natalie: Oh, yes, 'verify'. You have to learn me English too, yes? Because you learn much, much more than me.

Teego: No problem.

Natalie: Yes? So I want that you correct me when I'm wrong.

Teego: Yep, but often you are not wrong, like, only a couple of..., like,... only a few times and then I will correct you, of course.

Natalie: Yes, you can correct me. So what is the word, 'verific'?

Teego: 'Verify'.

Natalie: 'Verify'. So I will 'verific', 'verify', yes, I will 'verify', yes?

Teego: 'Verify'.

Natalie: Yes, thank you. I will 'verify' about this possibility for you, I will show to you the photos and if it is possible. I will show to you.

In the following example, Peregrino also assists Jujuba in the practice of English. Despite knowing the word that she needs to express 
her favorite area in tourism, Jujuba pronounces it wrongly. Peregrino then corrects her and reinforces his feedback by repeating the correct pronunciation of the word many times.

[7] - Interaction via Openmeetings

Peregrino: I don't know really what is your, like, what is your specialization, do you have some... what is really interesting for you? Like this, marketing? Do you like marketing or kind of...

Jujuba: No, no, I don't like...

Peregrino: What part of your studies do you, do you like? What do you like?

Jujuba: Events. (She pronounces the word with an initial/æ/)

Peregrino: Events? (He corrects the pronunciation of the word)

Jujuba: Eventos. Events, yes? (She repeats the word with an initial/i/)

Peregrino: Mhm, events, ok? Events. (He confirms the correct pronunciation)

Jujuba: Events.

Peregrino: Events.

Jujuba: Yeah, events.

In example [8], it is the Brazilian partner who assumes the role of assistant of his foreign peer. As Lini needs assistance, Gustavo helps her in the production of sentences in Portuguese. First, he corrects her by showing that the word 'museu' (museum) in Portuguese is a masculine word and as such it has to be preceded by the masculine article 'o' (no museu). Then he introduces the use of the form 'às' (at), which is used with specific times of the day.

[8] - Interaction via Openmeetings - 28th August 2010

Gustavo: Lini, o que você vai fazer hoje? O que você vai fazer hoje?

Lini: Provavelmente ... Provavelmente, vou ir na museu.

Gustavo: Ah, no museu?

Lini: Museu.

Gustavo: Museu. No museu.

Lini: No museu.

Gustavo: Que horas, Lini? Que horas você vai no museu?

Lini: Provavelmente duas ou três horas.

Gustavo: Ok. So, you can say, you can use this preposition. I will gonna highlight for you. Eu vou colocar para você. Você pode usar essa preposição aqui, ooh, this preposition 'às'.

Lini: às.

746 Gustavo: Às duas horas, às três horas. At three, at four... 
In example [9], Gustavo explains to Lini the use of the verb 'ir' ('to go') in the plural forms. Firstly, Gustavo shows her the form of second person plural in the simple past: 'vocês foram' (you went). She then asks him about the first person plural and, before getting the response from Gustavo, she herself says: "nós fomos" (we went). Gustavo then introduces to her the future tense. He illustrates, as examples of verbs in the future, the declinations 'Eu vou comer' (I am going to eat) and 'vou dormir' (I am going to sleep). Lini repeats these verb forms and contextualizes another example given by Gustavo ('vou viajar' - I am going to travel) and says: "vou viajar, erm, na quinta." (I'm going to travel, erm, on Thursday).

[9] - Interaction via Openmeetings $-28^{\text {th }}$ August 2010

Gustavo: O plural, Lini. O plural é isso aqui ooh... O plural seria assim... O plural seria esse ooh... 'vocês foram'.

Lini: Hum.

Gustavo: 'Vocês foram'.

Lini: E 'nós'?

Gustavo: Tem uma... Nós?

Lini: 'Nós fomos'.

Gustavo: Very good! 'Nós fomos'.

Lini: 'Fomos'.

Gustavo: Muito bem, Lini. E para falar no futuro. Para falar sobre o futuro, in the future tense, é muito simples, você pode falar assim ooh, for example, eu, 'eu vou comer', 'eu vou comer'. Eu...

Lini: Como em espanhol? Ah, eu vou. Mhm.

Gustavo: Exactly. Like I'm going to, I'm going to. Eu vou, aah, dormir... I think you won't have problems with this.

Lini: Mhm.

Gustavo: Bem legal.

Lini: 'Eu vou comer'. 'Eu vou dormir'.

Gustavo: 'Eu vou viajar'. 'Eu vou viajar'.

Lini: Vou viajar, erm, na quinta-feira.

Gustavo: Quinta-feira, quinta-feira.

Lini: Feira, feira.

Gustavo: Feira. Quinta-feira. Muito bom, Lini.

Lini also follows the principle of autonomy as presented by Brocco (2010) and Cavalari (2009), because she manages her own learning process by taking advantage of the interactions to question about the functioning of verbal structures in Portuguese. Not only does she 
produce linguistic output, but she also reflects on its operation, thus experiencing, through the elaboration of hypotheses, the process of learning a new language.

In the following example, it is Teego who takes the opportunity to assist Natalie in the learning of German, his native language. They were talking about places to stay, when Natalie asks Teego how to pronounce the article 'die' in German. The participants then engage in negotiations to clarify the pronunciation of this article. German was not a language to be learned in the teletandem sessions, but since it is Teego's mother tongue, he felt like introducing this language in the interactions.

[10] - Interaction via Openmeetings $-30^{\text {th }}$ August 2010

Natalie: How do you pronounce? Die Pension?

Teego: Die Pension.

Natalie: Die Pension.

Teego: Pension (He corrects the pronunciation of the word)

Natalie: Pension.

Teego: Yes, from... like, like a French word, but in a German kind of pronunciation.

Natalie: But it is 'die', 'die Pension'.

Teego: Yeah, perfect.

Natalie: I can't pronounce the, the 'ie'.

Teego: The what?

Natalie: In the first, in the first, in this word I can't pronounce the letter, the last letters.

Teego: It's, erm, yes, it's only 'die' because these letter ' $\mathrm{i}$ ' and ' $\mathrm{e}$ ' together form the sound of a longer 'e', or a long 'i' like /di:/.

Natalie: Ok, 'die'.

Teego: If they stand together you always say like /i:/.

Natalie: The, the two letters together I only say /i:/. Ah, ok.

Teego: And if they are the other way around, like 'e' and ' $i$ ', you pronounce like /ai/.

Natalie: No, repeat please.

Teego: /ai/.

Natalie: But it is the sound /ai/ when... when what?

Teego: When like... the first letter is ' $\mathrm{e}$ ' and the second one is ' $\mathrm{i}$ ', then you only say /ai/.

Natalie: /ai/, for example...?

Teego: Like, 'Ei' means 'egg', like, the 'egg' of a hen. 
In tandem learning, some topics such as the participants' experiences, way of life, and background knowledge can become spontaneous topics of conversation, which provide them with opportunities for language learning through authentic communication (Brammerts 1996). In fact, the issues related to daily life triggered the practice of vocabulary both in Portuguese and German. On the other hand, the English language arises when there is some misunderstanding in the messages and also as scaffolding to the learning of the other two languages.

\subsection{Talking about 'sustainability' and 'tourism' and the results of these interactions}

By interacting with one another, the participants had the chance to talk about the subthemes they had to investigate and to write some academic texts about them. In example [11], we can see Natalie and Teego negotiating about which tourist destinations they should choose to develop a research. To do so, Teego and Natalie, as postulated by Figueiredo (2006) and Forman and Cazden (1985), must work together to co-construct a project about 'sustainability' and 'tourism'. Natalie is the participant who knows about cultural aspects in the state of Goiás, and Teego is the one who knows theories on sustainable tourism. The Brazilian participant was able to give her partner information about all the places that the group of Brazilian and foreign students would visit in Goiás, because she had already visited those destinations for leisure and for academic purposes.

On the other hand, Natalie needed Teego's help in questions related to sustainability, because the Tourism course at IFG does not specifically address this issue in the lessons, although students studied the types of tourism that the literature of the area presents. Conversely, the University of Worms takes a more vertical approach to tourism and environmental issues. Moreover, the trip the foreign students made to 
Goiás was part of a subject they were taking at their Master's degree course that focused on management of international tourism, especially on environmental issues. Thus, Teego knew more about the subtheme Natalie and he would investigate. So, by working collaboratively, the participants would have the chance to put their knowledge together to come to terms with the project because the research would be difficult to accomplish if each member of the pair worked alone (Figueiredo 2006, Forman \& Cazden 1985). The negotiation we can see in example 11 focuses on the participants making decisions about which of the tourist destinations would be the best option for them to develop the subtheme they had chosen - 'Management concepts for sustainable destination'.

[11] - Interaction via Openmeetings $-26^{\text {th }}$ August 2010

Natalie: But, ah, what do you prefer? A city that don't, a place because Santa Branca is not a city, it is a place very next to Goiânia, but what do you prefer? A city that doesn't have a complete structure, ah, the basics structure of the tourism is not, is not completely construct until, until today, although, the city is a touristic point, the city doesn't have structures for this, for the tourism or another place that has everything complete, everything ok, everything complete to comfort the tourism, the tourist, what do you prefer?

Teego: It is best to have like one area that is already developed, that has everything for the tourist and another one which is not developed, so you can still say ok, erm, the other region has that problems and here we have still the chance to change, to change something, then makes better for the tourism and more sustainable wherever.

Natalie: Interesting. Is this because Pirenópolis is the first city because there is a very nice, a very good point, touristic point here, but there doesn't have the structure complete for this, so there has to development a lot of points, a lot of aspects for the tourism, but Santa Branca is the opposite, is completely ok, everything perfect. All the time that I go there I can't see nothing for to change, to change... everything ok there and Caldas Novas is in the middle way, is more developed, there has more development than Pirenópolis but is not so good like Santa Branca.

In the following example, we can see that this collaborative planning continues. Natalie and Teego talk about the presentations that each of them was doing at the institutions where they studied as a preparation for the working groups. Through Teego's speech, we 
can see that his perspective turns to theoretical concepts. On the other hand, Natalie's speech shows that she was working with data. In this perspective, the teletandem interactions nurtured, not only in Teego and Natalie, but also in all the other participants, an authentic and meaningful use of the English language, because they all brought, to the interaction process, their own knowledge, and with the help of one another they restructured it to express it in the foreign language. In the following excerpt, we can also see Teego and Natalie talking about the study that their working group would develop during the stay of the German students in Goiás. Again, we can observe the linguistic production of the pair of students, especially the long turns that certainly created opportunities for Natalie to get authentic input and to produce output in the language she was learning.

[12] - Interaction via Openmeetings $-30^{\text {th }}$ August 2010

Natalie: And what about the project? Are you preparing something, yeah?

Teego: Yes. We've prepared some, like, definitions and some basics we have to know, yeah?

Natalie: What kinds of definitions?

Teego: Like, what is sustainability and what is sustainable tourism and ... in comparison to ecotourism and adventure or nature tourism and something, then what're ... what ... like, how we wanna plan it, like, ... to do this concept thing, this tourism concept. And then we describe the management basics, like, first we have to analyze it, then we have, like, plan, organize, set the goals, aims, yeah, just some basics which are not really, like...

Natalie: Just some basics?

Teego: Yeah, well it's just, like, theoretically, so we didn't really compare or put it straight on the regions ... just some theoretical bases, what we are planning to do ... actually.

Natalie: Yes, I think some, some, some structures here to ... that you, that you told me in another meeting that you want to compare, I'm thinking about this too, I'm searching these areas here too. I selected some, some photos to pass, to pass to you, for you to saw some places too.

Teego: Yeah, that would be nice, yeah.

By interacting with each other, Natalie and Teego collaboratively outlined the project on 'sustainability and tourism': Teego helped his partner by providing her with the theoretical knowledge he had on the 
topic they were working with. Natalie, in her turn, collaborated with Teego by providing him with the knowledge she had on the destinations they would visit, Caldas Novas and Pirenópolis, since she lived near these cities and had visited them many times. Thus, following the perspective of collaborative learning, Natalie and Teego helped each other co-construct a common goal. There is no interference of a third person, like a teacher, in the definition of the activities each interactant will do. In an autonomous way, they themselves define their roles as the research develops. It is in this sense that teletandem sessions, conducted in a technological education context, promote the development of autonomy among the participants of the project.

The following excerpt brings an interaction between Jujuba and Peregrino. Peregrino was completing his master's degree at the University of Trier. Therefore, he had more experiences with the subtheme 'Performance measurement systems in sustainable tourism' than his partner Jujuba. For Rego (1995), the heterogeneity between learners can expand individual capabilities of their perception of oneself, of others and of the world around them.

In this sense, Peregrino stands as an attentive mediator for Jujuba's needs. By seeking to make his partner participate more actively in the working group, Peregrino seeks to expand the possibilities of Jujuba's participation by choosing a topic that is part of Jujuba's academic training. Peregrino's attitude towards making his partner feel comfortable with the topic chosen corroborates assertions by some scholars who deal with collaborative learning (Antón \& Dicamilla 1999, Brooks \& Donato 1994, Bruffee 1999, Clifford 1981, Figueiredo 2006, Oxford 1997, Swain 2000, Swain, Brooks \& Tocalli-Beller 2002, Warschauer 1997). According to these authors, collaborative learning encourages active participation of learners in the construction of the task, since they need to work together to achieve their goals.

[13] - Interaction via Openmeetings

Jujuba: But it is not easy, né?

Peregrino: I think it's easy.

Jujuba: I don't understand.

Peregrino: Would be like you...

Jujuba: No easy. 
Jujuba: Because...

Peregrino: Here on the left is like... erm...

Jujuba: Uh?

Peregrino: Like this, you have one scenario, it's like when a tourist comes to Rio and he goes to the beach and to the clubs or another stuffs, that's the left scenario, the trip like one week, that they stay in Brazil, ah, how much emissions will be emitted? And the other scenario would be, for example, Chapada or Pirenópolis, they're doing sustainable tourism and then would be less emissions, so we calculate them both and then we, we make a comparison. What do you think?

Jujuba: But it's the emissions of the car, bus or the people?

Peregrino: Mhm, can be everything, the... erm... like, for example, the tourists in Rio, if they use the car or a lot of taxi, so it would be the taxi, it would be the hotel, it would be the use, the, the air conditioner, so it's all, all this kind of stuff what you normally use.

Jujuba: Ah, ok.

Peregrino: It's like, like a...carbon footprint, do you know?

Jujuba: carbon footprint, ok.

Jujuba does not follow what Peregrino says in a passive way. On the contrary, she asks questions, reflects on the information he gives and interferes with what he says. Thus, by asking if Peregrino was talking about carbon emissions from car, bus or persons, Jujuba emphasizes that the investigation on carbon emissions in a tourist area is a very broad focus, so it would be important for them to narrow down the focus of their research.

The following example shows an excerpt from a scholarly production resulting from the interactions in the teletandem sessions: the poster. The example describes some of the data collected by the participants during the visit to Chapada dos Veadeiros regarding tourist guides, environmental policies and investments.

[14] -Poster elaborated by Gustavo andLini

Title: Sustainable Tourism - Destinations of Cerrado Conditions

RESULTS

Through field researches, the group created "pros" and "cons" overviews related to sustainability and for the last ones, there were elaborated suggestions in order to solve the problems that were found. 


\begin{tabular}{|l|l|}
\hline 1 & Tourist guides and their importance \\
1.1 & PRO: presence of tourist guides; \\
\hline 2 & CON: lack of community involvement, low salaries; \\
2.1 & Investors \\
2.2 & CON: lack of promotion of local identity and regional events; \\
& PRO: inexistence of useless constructions at Parque Nacional da Chapada \\
\hline 3 & Environmental policies \\
3.1 & CON: There is no clear strategy of preservation and conservation of the \\
3.2 & natural resources; \\
& PRO: strict policies regarding leaving trash inside the area of the National \\
& Park; \\
& PRO: inexistence of vehicles inside the National Park. \\
\hline
\end{tabular}

The following example shows part of an article that was written by Natalie, Teego, and a German student who took part in another pair of interactants, whose pseudonym is Red. Red was doing research on 'Management concepts for sustainable destination', and since this subtheme was also being investigated by Natalie and Teego, they decided to write the article together. A relevant factor in this collaborative production of the article is the presence of reciprocity. According to Benedetti (2010) and Brocco (2010), the reciprocity principle is sustained by responsibility, and even though these authors were talking about reciprocity in teletandem sessions, this quality is also present in the co-construction of the article. So, Natalie, Teego and Red acted with great commitment and responsibility for the academic productions to be done. As is shown by Aranha \& Cavalari (in this issue), teletandem sessions also have the potential to help the participants improve their writing skills. 
[15] -Part of the article written by Natalie, Teego and Red

These two academic productions demonstrate, in the form of written texts, how the interactions via Openmeetings allowed the Brazilian learners not only to get in contact with foreign learners, but, in collaboration with them, to co-construct new knowledge. This knowledge refers to the fact that they have learned theories about 'tourism and sustainability' as well as that they had the chance to learn a new language or to improve a language they were already learning. In this sense, the use of teletandem sessions is a very fruitful approach to be used in technological education contexts. We could see that the discussions about 'tourism and sustainability' contributed to the relevance of the language learning process. In turn, the language learning process via teletandem provided the means for such learning: interactions via Openmeetings, the construction of academic knowledge, and, as a result, the production of academic texts.

From this perspective, we believe that learning via teletandem can contribute to the teaching and learning of languages in technological contexts mainly because the interactions through a computer application software allows learners for the practice of oral language and other skills, as well as for the work with different linguistic aspects in consonance with contents of other fields of knowledge. 


\section{Final remarks}

Openmeetings proved to be a useful web conferencing software to use in teletandem language sessions. The chat and the whiteboard were important tools to complement microphone and webcams during the interactions. The use of all these resources made the teletandem approach more similar to face-to-face interactions, as it enabled learners to feel as if they were in the same physical environment with their partners.

As for language learning, to analyze how much has been learned is a virtually impossible task, since our research does not provide the data for such analysis. However, we can state that the participants dealt with some lexical categories, as well as talked about the construction of a few sentences. This approach provided the learners with an opportunity to practice the language orally and to write the language by using the chat tool, and this conjunction of media allowed for the visualization of the written record of the words being learned. As for language learning, the English language played the role of an anchoring language for the learning of the other two languages: German and Portuguese. The practice of vocabulary was only focused in English when, during the interactions, communication failure occurred and one member of the pair felt the need for further clarification of the term in focus to better understand the message. By having to interact in English, the Brazilian participants had an opportunity for oral practice of that language and therefore they had their goal of improving fluency in that language somehow met. The objectives of the foreign students to learn Portuguese were also partially met, because they could make use of that language during the interaction sessions.

The participants of our study have no theoretical or practical knowledge about how to teach languages. However, the data also allow us to affirm that the participants of this study considered the teletandem sessions as a context for teaching and not only for learning. In this sense, we agree with the vision of the pioneers of the Teletandem Brasil Project that teaching and learning are intertwined in this context. In this study, participants are regarded as learners and as people who can teach something to their partners. 
The tandem learning, as postulated by Brammerts (1996), is a form of learning in which learners work collaboratively to enhance language skills, get to know each other and their culture, and, in some partnerships, also share information about their professional lives. Hence, the interactions between the participants of this study demonstrated that they sought to share linguistic knowledge, as well as to know about the personal, professional and academic lives of one another.

Taking into account that IFG is an institution that promotes technological education and that Worms and Trier also have the same context of education, the discussion about issues related to academic training, specifically on the themes 'sustainability and tourism', flowed naturally in the interactions. In this sense, teletandem learning became a generator of creative learning activities, enabling the Brazilian participants to improve their knowledge on the themes they were working on and to enhance fluency in the English language. The foreign participants also benefited from learning in teletandem, because in addition to having started learning Portuguese, through the interactions with their partners, they had the opportunity to visit the state of Goiás, where they were able to experience the use of this language in an immersion context. Some of the foreign participants, as we were told, continue to study Portuguese and develop studies on tourism in Goiás and on the use of clean technologies. We could also see some German students who became quite fluent in Portuguese. When Teego was in Goiás, in September 2011, he was speaking Portuguese fluently. $\mathrm{He}$ also informed us that he had presented the paper he and Natalie had elaborated at an international tourism fair in Berlin. He and Natalie continue interacting with each other via Openmeetings and through other digital media.

Moreover, the Brazilian participants took part in academic events, and in one of them they presented their posters in English. They also produced, in collaboration with their foreign partners, expanded abstracts, and scientific articles in English. In this sense, the purpose of knowing and investigating tourism and environmental preservation issues in Goiás yielded results that exceeded our expectations for the use of teletandem learning in a technological context: the production of academic texts in English. 
Finally, the use of teletandem learning brought a significant difference to the context of technological education at IFG, because after having participated in this research, the Brazilian students proved to be much more motivated to learn English when they realized a purpose for learning it: to use the language to express who they are and to know who the other is.

Received in March, 2015

Accepted in August, 2015

E-mails:

fquaresma@terra.com.br suelenevaz@yahoo.com.br

\section{References}

Antón, Marta; Dicamilla, Frederick. J. 1999. Socio-Cognitive Functions of L1 Collaborative Interaction in the L2 Classroom. The Modern Language Journal 83/2: 233-247.

AraúJo, Júlio \& Nukacia Araújo (org.). 2013. EaD em tela: docência, ensino e ferramentas digitais. Campinas, S.P.: Pontes Editores.

BeLz, Julie A. 2002. Social dimensions of telecollaborative foreign language study. Language Learning \& Technology 6/1: 60-81.

Benedetti, Ana Mariza, Douglas Consolo \& Maria Helena Vieira-Abrahão (orgs.). 2010. Pesquisas em ensino e aprendizagem no teletandem Brasil: línguas estrangeiras para todos. Campinas, S.P.: Pontes Editores.

Benedetti, Ana Mariza. 2010. Dos princípios de tandem ao teletandem. In: Benedetti, Ana Mariza, Douglas Consolo \& Maria Helena VieiraAbrahão (orgs.). Pesquisas em ensino e aprendizagem no teletandem Brasil: línguas estrangeiras para todos. Campinas, S.P.: Pontes Editores.

BrammerTs, Helmut. 1996. Tandem language learning via the internet and the International E-Mail Tandem Network. In: Little, David \& Helmut Brammerts (ed.). A guide to language learning in tandem via the Internet. CLCS Occasional Paper 46: 9-22.

2002. Aprendizagem autónoma de línguas em tandem: desenvolvimento de um conceito. In: Delille, Karl Heinz (org.). Aprendizagem autónoma de línguas em tandem. Lisboa: Edições Colibri. 
Brocco, Aline de Souza. 2010. Uma experiência de aprendizagem de português em contexto teletandem: a questão da gramática. In: Benedetti, Ana Mariza, Douglas Consolo \& Maria Helena VieiraAbrahão (orgs.). Pesquisas em ensino e aprendizagem no teletandem Brasil: línguas estrangeiras para todos. Campinas, S.P.: Pontes Editores.

Brooks, Frank B.; Donato, Richard. 1994. Vygotskyan approaches to understanding foreign language learner discourse during communicative tasks. Hispania, 77: 262-274.

BRUfFeE, Kenneth A. 1999. Collaborative Learning: Higher Education, Interdependence, and the Authority of Knowledge. London: The Johns Hopkins University Press.

Cavalari, Suzi Marques S. 2009. A auto-avaliação em um contexto de ensino-aprendizagem de línguas em tandem via chat. $258 \mathrm{f}$. Tese (Doutorado em Estudos Linguísticos) - Instituto de Biociências, Letras e Ciências Exatas, Universidade Estadual Paulista, São José do Rio Preto, 2009.

. 2010. As definições das metas e o processo de autoavaliação no contexto teletandem. In: Benedetti, Ana Mariza, Douglas Consolo \& Maria Helena Vieira-Abrahão (orgs.). Pesquisas em ensino e aprendizagem no teletandem Brasil: línguas estrangeiras para todos. Campinas, S.P.: Pontes Editores.

Chinnery, George M. 2014. CALL me... Maybe: A framework for integrating the Internet into ELT. English Teaching Forum 52/1: 2-13.

Clifford, John. 1981. Composing in stages: the effects of a collaborative pedagogy. Research in the Teaching of English 15/1: 37-58.

Figueiredo, Francisco José Quaresma de. 2006. A aprendizagem colaborativa de línguas: algumas considerações conceituais e terminológicas. In: Figueiredo, Francisco José Quaresma de (ed.). A aprendizagem colaborativa de línguas. Goiânia, GO: Editora da UFG.

Forman, Ellice Ann \& Courtney B. Cazden. 1985. Exploring Vygotskian perspectives in education: the cognitive value of peer interaction. In: Wertsch, James V. (ed.). Culture, communication, and cognition: Vygotskian perspectives. Cambridge: Cambridge University Press.

Foster, Pauline. 1998. A classroom perspective on the negotiation of meaning. Applied Linguistics, 19/1: 1-23.

Gass, Susan M. 1997. Input, Interaction, and the Second Language Learner. New Jersey: Lawrence Erlbaum Associates. 
Hasnawi, Sami B. Al. 2013. Intercultural Communicative Competence Development In Teletandem Learning Context. Available at: <http:// linc.mit.edu/linc2013/proceedings/Session4/Session4AlHasnawi. pdf > . Access on: 5 Jan. 2015.

LEONE, Paola. 2014. Teletandem, video-recordings and usage-based tasks: developing a socially situated scenario for learning. International Journal of Learning, Teaching and Educational Research, 9/1: 41-50.

Long, Michael H.; PorTer, Patricia A. 1985. Group work, interlanguage talk, and second language acquisition. TESOL Quarterly, 19/2: 207-228.

Luvizari-Murad, L. H. 2011. Aprendizagem de alemão e português via teletandem: um estudo com base na teoria da atividade. $204 \mathrm{f}$. Tese (Doutorado em Estudos Linguísticos) - Instituto de Biociências, Letras e Ciências Exatas, Universidade Estadual Paulista, São José do Rio Preto.

Luz, Emeli Borges Pereira. 2010. Teletandem: ambiente favorável para o desenvolvimento da autonomia do aprendiz. In: Benedetti, Ana Mariza, Douglas Consolo \& Maria Helena Vieira-Abrahão (orgs.). Pesquisas em ensino e aprendizagem no teletandem Brasil: línguas estrangeiras para todos. Campinas, S.P.: Pontes Editores.

Mackey, Alison. 1999. Input, Interaction, and second language development. Studies in Second Language Acquistion, 21: 557-587.

O'Dowd, Robert. 2011. Online foreign language interaction: moving from the periphery to the core of foreign language education? Language Teaching, 44/3: 1-20.

OXFORD, Rebecca L. 1997. Cooperative learning, collaborative learning, and interaction: Three communicative strands in the language classroom. The Modern Language Journal, 81/4: 443-456.

PaIVA, Vera Lúcia Menezes de Oliveira E. 2001. Interação e aprendizagem em ambiente virtual. Belo Horizonte/MG: Faculdade de Letras, UFMG.

PICA, Teresa. 1991. Classroom interaction, negotiation, and comprehension: redefining relationships. System, 19/4: 437-452.

. 1994. Research on negotiation: what does it reveal about secondlanguage learning conditions, processes, and outcomes? Language Learning, 44/3: 493-527.

REgo, Tereza Cristina. 1995. Vygotsky: uma perspectiva histórico-cultural da educação. Petrópolis/Rio de Janeiro: Vozes.

Silva, Suelene Vaz da. 2012. O processo ensino-aprendizagem de línguas em teletandem: um estudo na área de Turismo. $293 \mathrm{f}$. Tese (Doutorado em Letras e Linguística) - Faculdade de Letras, Universidade Federal de Goiás, Goiânia. 
SouzA, Ricardo Augusto de. 2003. Aprendizagem de línguas em tandem: estudo da telecolaboração através da comunicação mediada pelo computador. 269 f. Tese (Doutorado em Linguística Aplicada) Faculdade de Letras, Universidade Federal de Minas Gerais, Belo Horizonte.

SwaIN, Merrill. 1995. Collaborative dialogue: its contribution to second language learning. Revista Canaria de Estudios Ingleses, 34: 115132.

.2000. The output hypothesis and beyond: mediating acquisition through collaborative dialogue. In: Lantolf, James P. (ed.). Sociocultural theory and second language learning. Hong Kong: Oxford University Press.

Swain, Merrill; Brooks, Lindsay \& Tocalli-Beller, Agustina. 2002. Peer-peer dialogue as a means of second language learning. Annual Review of Applied Linguistics, 22: 171-185.

SwaIn, Merrill; LAPKIN, Sharon. 1998. Interaction and Second Language Learning: Two Adolescent French Immersion Students Working Together. The Modern Language Journal, 82/3: 320-337.

Telles, João Antonio (ed.). 2009a. Teletandem: um contexto virtual, autônomo e colaborativo para aprendizagem de línguas estrangeiras no século XXI. Campinas/S.P.: Pontes Editores.

TelLes, João Antonio. 2009b. Teletandem: conceito e ações para a prática e pesquisa. In: Telles, João Antonio (ed.). Teletandem: um contexto virtual, autônomo e colaborativo para aprendizagem de línguas estrangeiras no século XXI. Campinas/S.P.: Pontes Editores.

Telles, João Antonio \& Maria LuisaVassallo. 2009. Teletandem: uma proposta alternativa no ensino/aprendizagem assistidos por computadores. In: TelLes, João Antonio (ed.). Teletandem: um contexto virtual, autônomo e colaborativo para aprendizagem de línguas estrangeiras no século XXI. Campinas, S.P.: Pontes Editores.

Vassallo, Maria Luisa \& João Antonio Telles. 2006. Foreign language learning in-tandem: Teletandem as an alternative proposal in CALLT. The ESPecialist, 27/2: 189-212.

2009. Ensino e aprendizagem de línguas em tandem: princípios teóricos e perspectivas de pesquisa. In: Telles, João Antonio (ed.). Teletandem: um contexto virtual, autônomo e colaborativo para aprendizagem de línguas estrangeiras no século XXI. Campinas/S.P.: Pontes Editores.

Vygotsky, Lev. 1978. Mind and Society. Cambridge, MA: Harvard University Press. 
31.3

2015

Warschauer, Mark. 1996. Computer Assisted Language Learning: an Introduction. In: Fotos, Sandra (ed.). Multimedia language teaching. Tokyo: Logos International.

1997. Computer-mediated collaborative learning: theory and practice. Modern Language Journal, 81/3: 470-481. 